\title{
1. Small states: concepts and theories
}

\author{
Godfrey Baldacchino and Anders Wivel
}

\section{INTRODUCTION}

Small states are more visible and prominent than at any other point of world history (Hey, 2003, p. 1). The combined effect of the collapse of empires, the rise of nationalism and the strengthening of an institutional international architecture, including a widening of the respect and rule of law, since the end of the Second World War has served as a vehicle for the proliferation of small sovereign states. As noted by Neumann and Gstöhl (2006, p. 3), "small states are simply too numerous and - sometimes individually, but certainly collectively - too important to ignore". This volume offers a timely, rich and systematic review of the politics of small states. The authors assess the opportunities as well as the challenges of small state politics and discuss problems of marginalization and the strategies that small states deploy in order to influence the fate of their own societies and that of regional and global affairs.

For many of these small states, their fundamental problématique has been transformed. Their physical security and territorial integrity is rarely threatened as it was in the past (Løvold, 2004), and 'extantism' - once a state, always a state - is alive and well in the twenty-first century (Bartmann, 2002, p. 366): the last attempt to 'eliminate' a state was probably the invasion, and subsequent annexation, of Kuwait as the nineteenth province of Iraq in August 1990. And yet, at the same time, the political action space of small states has been restricted in both domestic politics and international affairs. Globalization has proven to be a double-edged sword for small states allowing most of them to boost trade and avoid poverty, but at the same time increasing vulnerabilities and dependency for many as a consequence of unconventional security risks stemming from mass migration, terrorism, money laundering and environmental degradation (Bailes, Rickli, and Thorhallsson, 2014). The increasing number, complexity and detail of international institutions have helped to level the playing field in international affairs by allowing small states a bigger voice and more platforms and arenas where to seek influence; but this development has also restricted their autonomy and applied more pressure on their limited and thinly-stretched diplomatic and administrative resources.

The central aim of this book is to identify the most important characteristics, challenges and opportunities facing the politics of small states today. We identify the historical legacy and explanatory factors influencing small state politics and unpack the costs and benefits of different models for doing politics in small states. The book seeks to answer three general questions: What are the characteristics of the politics of small states? What are the major opportunities and challenges of policy-making and policy implementation in small states? How do small states respond to these oppor- 
tunities and challenges? Furthermore, the coherence of the volume is underpinned by a temporal focus on the present and recent past (10-20 years), with a historical contextualization provided only when this is relevant for understanding current small state politics.

The aim of this chapter is to set the scene for the book. We do so in five stages. First, we tackle the perennial problem of defining what we mean by a 'small state'. While this topic seems to have taken up an excessive amount of space in the literature on small states, we seek a functional and pragmatic definition that allows us to fulfil the aim of the book: to analyse the politics of small states. Second, we start from this definition to draw the contours of the political space inhabited by small states by identifying three dilemmas of small state politics in order to briefly identify some of the challenges that these states share because they are small. The third section explains the structure of the book, while the fourth section sums up the major findings of the book and draws lessons from the analyses of the book to identify a number of promising future research trajectories on the politics of small states before the chapter is concluded.

\section{WHAT IS A SMALL STATE? WHY DOES IT MATTER?}

There exists no consensus definition of small states and the borderlines between such categories as 'micro state', 'small state' and 'middle power' are usually blurred and arbitrary (Mouritzen and Wivel, 2005; Raadschelders, 1992). The lack of a consensus definition is not a problem tied exclusively to the study of the politics of small states. In any case, and certainly in the social sciences, consensus on how to define central concepts is rare, and disagreement over how to understand central concepts such as democracy or power has not - and should not - stop us from studying these important aspects of world politics, just as much as it should not hinder us from studying small states (Amstrup, 1976; Baldacchino, 2018). However, debates on how to define and categorize small states have played an excessively dominant role in the study of small states for the past 50 years. On the one hand, these debates have created a "fundamental definitional ambiguity", which "has hindered theory building [and] complicated comparison" (Long, 2017, p. 144). On the other hand, definitional discussions have provided a fertile ground for a pluralist study of small states and a continuing discussion of the meaning and consequences of smallness for doing politics (Maass, 2009). In that sense, the study of small states can even be viewed as avant-garde by preceding and foregrounding more recent discussions on the virtues of eclecticism, and the benefits of mid-level analysis addressing specific and important real-world problems over grand theorizing (Lake, 2013; Sil and Katzenstein, 2011).

Despite the fogginess of the small state concept, few people question that small states exist or that small states share a number of challenges (Archer, Bailes and Wivel, 2014; Baldacchino, 2018; Cooper and Shaw, 2009; Knudsen, 2002). However, the lack of a consensus definition necessitates a brief discussion about how we define 'small state' in this book, and why we make this choice. While we reject 
any attempt at an essentialist, universal definition of small states, we acknowledge that definitions do matter. The manner in which we define small states has both analytical and political implications. As noted by Christopher Browning, "size has generally been connected to capability and influence. Whilst being big is correlated with power, being small has been viewed as a handicap to state action, and even survival" (Browning, 2006, p. 669).

The literature on small states includes many definitions of small size; but this corpus can be largely distilled into three, ideal-type definitions.

\section{Ideal-Type 1: 'Non-Great' Powers}

First, the simplest way of defining small states is to see them as those states that are not great powers. This ideal-type corresponds well to how a small state is understood in political discourse in most countries, and it has deep historical roots. Traditionally, small states and great powers played very different roles in international relations. During the European Concert (1815-1914), all states except Austria, Prussia, Russia, the United Kingdom and France were small states. The great powers took responsibility for maintaining stability and writing international law, while small states were the rule takers, free of systemic responsibility, but at the same time suffering from a limited political action space, particularly when it came to foreign relations (Neumann and Gstöhl, 2006, pp. 2-5). More recently, permanent membership of the United Nations (UN) Security Council, possession of nuclear weapons, or the deployment of an aircraft carrier have been used as thresholds for great power status (e.g. Handel, 1990, p. 12; Cooper and Scobell, 2014). However, this would relegate Germany to the status of a non-great power, since it has none of these. In contrast, France would be a great power: it has nuclear weapons, an aircraft carrier as well as a permanent seat at the UN Security Council.

\section{Problems with this definition}

And yet, would not this be a rather counter-intuitive classification after the recent power shifts in Europe, and including 'Brexit', leaving Germany with close to hegemonic status in both economic and political affairs? Likewise, countries such as Spain and Turkey have been viewed as non-great powers (Fox, 1959, 1969). Krause and Singer simply propose a list of nine great powers in overlapping intervals of international world history since 1816: Austria-Hungary, China, France, Germany/ Prussia, Italy/Sardinia, Japan, Russia/USSR, the United Kingdom and the United States, and which they claim to identify according to "scholarly consensus" (Krause and Singer, 2001, p. 15). Alternatively, small states may be viewed as those states that are neither great powers, nor consistently striving for middle power status, but this still leaves a small state as a residual category (Neumann and Gstöhl, 2006, pp. 5-6). In sum, neither a great power, nor a small state in the world today, are as self-evident as in the nineteenth century. By characterizing small states as 'not great powers', 'small states' become a residual or leftover group, which at the same time paradoxically - constitutes the large majority of states in the world. 


\section{Ideal-Type 2: Material Assessment}

The second ideal-type focuses on the absolute or relative material capabilities of small states. Small states are states lacking power capabilities, most notably military capability (Rickli and Almezaini, 2017, pp. 9-10) and, as noted by Handel, this resource is related to population size: "[h]istorically, the single most important yardstick for the measurement of military power has been the population size of a given state" (Handel, 1990, p. 13). Military capability permits a projection of state power beyond its territory; it creates the potential for military actions with or against other states; and builds domestic defensive capability or deterrent in case of invasion or attack. Some small states, recognizing their clear inability to project military force, have opted to dismantle their armed forces, or abandon their formation, whittling down their security forces to basic and humanitarian, 'search and rescue' operative teams (Bartmann, 2007, p. 299). This definition allows us to identify absolute and relative limitations to small states' capacity to handle different types of challenges and to create a clear and easily applicable definition of small states, i.e. get a more clear-cut definition than when defining small states as 'not great powers'.

\section{Problems with this definition}

However, defining small in terms of capabilities, i.e. the possession of power resources in absolute or relative terms, suffers from at least two challenges. First, where is the cut-off point between those that are small states and those that are not? For instance, while the World Bank identifies a population of 1.5 million as the threshold, others venture as high as 16 million (e.g. the Netherlands in the EU) or 25 million (e.g. Madagascar in Africa) (World Bank, 2017; Marriott, 1943; Molis, 2006). Likewise, why would we rank, say, the three, five or seven states in Africa with the largest population or GDP as 'great powers' and relegate the rest of that continent's states to the category of 'small states'? Second, which absolute or relative criteria should be used for determining which states are small: gross domestic product (GDP), resident population size, defence expenditure, or something else? The diminishing return of military conquest over the past century has altered which capabilities are important for any state, and small states in developing countries often have larger populations than economically advanced small states in Europe and East Asia (Vital, 1967). Moreover, a focus on material power resources typically leads to a focus on military security, because material resources are so closely coupled to the military survival of the state (Wivel, Bailes and Archer, 2014, p. 7). Even human and economic resources tend to be regarded as 'latent power' providing the base for the military superstructure (Mearsheimer, 2014). This is less useful to the aims of this volume, which seek to understand the politics of small states, and not just their alliance choices, military expeditions and/or defence policies. 


\section{Ideal-Type 3: Political Constructs}

The third ideal-type views the small state as a political construct. To paraphrase Alexander Wendt (1992), size is what small states make of it. According to this view, 'small states' are constructed by the perceptions and preferences of the people and institutions of the small state as well as of other states (Thorhallsson, 2006, 2012). This allows us to decouple the concept of small states from materialist, national security considerations, which follow from the power possession definition. Thereby, it potentially provides an optimistic contrast to the rather pessimistic prospects for small state politics as defensively focused on survival and security.

\section{Problems with this definition}

Nevertheless, and for all its attraction, were this definition to stand alone, it would also risk overemphasizing the freedom of action and opportunities of small states, turning a blind eye to the inequalities between small states and great powers and between different types of small states. Thus, for a rich, stable and democratic (albeit small) NATO member state such as Norway (population: 5.2 million), opportunities may abound; but for Lebanon, Liberia or Jordan, or even fellow NATO member state Estonia, the challenges emerging from limited capacity and power asymmetry, including turbulent geopolitical neighbourhoods, may be both real and acute.

\section{FOR A SYNTHETIC DEFINITION}

Given the limitations of each of these three ideal-types, it is no surprise that there have been various attempts at creating a blended definition of a small state, combining 'objective' material criteria with the perceptions and constructions of domestic and foreign elites (Archer and Nugent, 2002; Värynen, 1971). While these combinations allow more nuanced definitions of small states to be proposed, they also run the risk of importing the multiple weaknesses of the ideal-type definitions into a new and more complicated designation. Therefore, we take a different route towards a workable definition for analysing the politics of small states.

First, our starting point is that small states are states. In accordance with modern customary law and the 1933 Montevideo Convention, small states must have a defined territory, a permanent population and a government in control, and are willing to participate in international relations (Maass, 2017, pp. 21-22). Thus, small states are legally sovereign, but their actual autonomy may vary. This volume takes legally sovereign states as its point of departure and primary object of study. It uses legal sovereignty as a baseline when embarking on analyses and discussions on variations of the autonomy of territories and regions.

Second, rather than trying to arrive at a universal definition of what constitutes a small state across time and space, we accept as our starting point that being a small state is tied to "a specific spatio-temporal context" (Thorhallsson and Wivel, 2006, p. 654). From this point of departure, it makes little sense to define small states 
according to a specific population or other absolute or relative criteria and then apply that definition through time and space.

This leads us to a pragmatic working definition identifying two characteristics of small states and serving as a point of departure for the analyses of this volume. First, small states are states that are characterized by the limited capacity of their political, economic and administrative systems. For this reason, they are prone to experience reduced competition and a monopolistic or oligopolistic arrangement in the marketplace of ideas, in the economy as well as the race for political and administrative office (Armstrong et al., 1993; Murray, 1981). However, they are also well positioned for enjoying the benefits of informality, intense personalization and a less hierarchical society (Baldacchino and Veenendaal, 2018; Baldersheim and Keating, 2015; Corbett and Veenendaal, 2018; Thorhallsson, 2019). Consequently, this volume explores the political effects of limited capacity and the structural distortions of 'free markets' and 'perfect competition' in small states.

Additionally, small states typically find themselves as "the weaker part in an asymmetric relationship, unable to change the nature or functioning of the relationship on [their] own" (Wivel, Bailes and Archer, 2014, p. 9) as well as "stuck with the power configuration and its institutional expression, no matter what their specific relation to it is" at both the regional and global level (Mouritzen and Wivel, 2005, p. 4). Thus, in external relations, the consequences of limited capacity are exacerbated by power asymmetry, leaving small states to struggle with being price and policy takers overall: with being hard put to manage security threats; with limited diplomatic power when seeking to influence international negotiations and institutions; with a chronic openness to international trade regimes; and with a vulnerability to various other external, economic or environmental shocks (Armstrong and Read, 2002; Briguglio, 1995; Cooper and Shaw, 2009; Thorhallsson and Steinsson, 2017; Värynen, 1971). And so, this volume also explores the effects of power asymmetry for small states.

\section{THREE DILEMMAS OF SMALL STATE POLITICS}

The number of small states has waxed and waned over the centuries. Although it is a common assertion that the number of small states is now at a highpoint in world history, this is actually not the case (Maass, 2017, pp. 34-36). Counting from the end of the Thirty Years War in Central Europe (1618-1648) and the Treaties of Westphalia - the yardstick most often used for signifying the beginning of the modern state system - the number of 'small states' - defined as structurally irrelevant units of the states system (Maass, 2017, p. 18) - fell from more than 430 to around approximately 150 today. ${ }^{1}$ This was due to a combination of successive wars in

In his database, Maass categorizes all states for every year since 1648, identifying both the absolute number of small states and the ratio of small states to large states in the system. 
Europe and development of military technologies, making it increasingly difficult for small and autonomous political entities to defend themselves; as well as the voluntary or forced amalgamation of smaller political entities to compose larger states, most importantly Germany and Italy, often with strident appeals to nationalism (Wimmer, 2012).

To many contemporary observers, the first half of the twentieth century - including two world wars and a significant increase in the destructive arsenal of great powers - heralded the comprehensive demise of the small state altogether. As noted by Annette Baker Fox in her classic study of the power of small states, "[d]uring World War II, it was widely asserted that the day of the small power was over. Not only could such a state have no security under modern conditions of war; it could have no future in the peace that presumably one day would follow" (Fox, 1959, p. 1). However, the end of the Second World War also marked the end of the downward trend in the global number of small states, which has since risen by approximately 100 , most importantly as a consequence of the demise of empires and the strengthening of the norm of national self-determination. In 1946, Iceland became the smallest member of the United Nations (UN), with a population of 300,000. Today, 23 UN member states each have a resident population smaller than Iceland; and, of the 193 UN member states, more than 100 participate in the informal grouping, titled the Forum of Small States (FOSS), initiated by Singapore in 1992 (Kassim, 2012; see also Iceland UN Mission, 2008).

The politics of small states has changed radically over the past two centuries, creating new challenges and opportunities. In particular, we can identify three pressing dilemmas in small state politics.

\section{The Nationalist/Cosmopolitan Dilemma}

Since the mid-nineteenth century, nationalism has played a central role in the creation of new small states, the lingering of old small states (as with the European continental microstates) and occasionally in the (voluntary or involuntary) demise of small states integrated into larger entities: think Zanzibar, Somaliland or South Yemen. This is true for nineteenth- and twentieth-century small state perseverance in the face of the threat of domination and annexation from great powers, as well as in the small states created by decolonization and post-Cold War geopolitics. Yet, for small states, nationalism is a double-edged sword. On the one hand, it is a necessary condition for the survival of small states, creating a unifying socio-cultural fabric and a historical narrative which legitimates the state and unites people under one flag (Anderson, 2006). On the other hand, small states have a strong interest in containing and delegitimizing the irredentist exercise of national interests by the great powers as this may threaten their action space or even their very survival (e.g. Paci, 2015). They tend to do so by championing cosmopolitanism and eschewing isolationist policies (unless forced to do so: think Cuba and Taiwan). Moreover, with the dramatic secession of Tuvalu from already small Kiribati, or of Anguilla from small St Kitts-Nevis, it seems that no state is small enough to prevent internal fission and fragmentation 
(Clarke, 1971; McIntyre, 2012). Thus, small states face a dilemma between promoting the national values and characteristics of their own societies at home in order to secure a strong base for national policy-making; and promoting cosmopolitan values internationally to curb encroaching nationalist challenges peddled by outsiders.

\section{The Democratization/Group Think Dilemma}

Democratization has transformed the politics of small states (Corbett and Veenendaal, 2018). Small states are sometimes viewed as more democratic than larger states, because small size typically means a short distance between the population and the political elite, and because small states are viewed as more coherent political communities than larger states (Ott, 2000; Richards, 1982; Srebrnik, 2004). However, this is not necessarily the case. Smallness can usher in a lack of pluralism, reduced choice and significant social pressures to conform to dominant 'codes' (Baldacchino, 2012; Dahl and Tufte, 1973). Even in the Nordic countries - well known for their tightly knit political communities and egalitarian and consensus seeking polities - divisions between highly educated city elites and rural areas feeling left behind are evident; and have become manifest in the current wave of populist politics. Moreover, small states are prone to small and tightly knit political and economic elites without sufficient counterbalancing coalitions, enhancing the risk of 'group think' (Janis, 1982), lack of innovation, but also corruption and personalized politics (Corbett, 2015; Corbett and Veenendaal, 2018).

\section{The Influence/Autonomy Dilemma}

The intertwined increase in interdependence and interaction capacity - the capacity for communication, transportation and organization (Buzan, 1993, p. 331) - from the early nineteenth century and onwards has changed the conditions for policy-making within small states as well as the conditions for small state external relations. The invention and subsequent proliferation of transport and communications technologies, including the airplane, the Internet and the World Wide Web, as well as developments in weapons technology leading to a massive increase in the destructive power of the great powers and their ability to fight wars far from home, mean that the threats and opportunities of small states are no longer confined to their geopolitical vicinity, as was the case for the first centuries of the modern state system. Moreover, these developments have been accompanied by an increase in the organizational capacity of the world system and the collapse of progress in multilateral trade agreements, crafting the 'spaghetti bowl' character of a 'new regionalism' with multiple overlapping agreements (Alter and Meunier, 2009; Menon, 2014). For small states, these developments have contributed to the reduction of interstate warfare since the end of the Second World War, thereby reducing the traditional survival problem of most small states. However, small states now face a more acute dilemma between policies aimed at maximizing autarchy and national autonomy versus policies 
seeking to secure international influence; even though small states do not have much choice but to follow the winds of economic liberalism.

The study of small states has grappled with these dilemmas and their effects on small state politics, leading to both optimistic and pessimistic assessments about the present and future opportunities for small states, and their ability to successfully develop their societies. The ambition of this volume is neither to parade small states as sophisticated examples of 'best practice', nor to shame them as dysfunctional trouble makers. That would be naively simplistic, unfair and incorrect. At least to some extent, both gloomy and rosy valuations have often been a function of case selection (Wivel, 2016, pp. 93-95). Instead, our ambition is to combine a state-of-the-art overview of small state politics with cutting edge analyses of the present and future opportunities and challenges of small states. The next section explains how we structure the book in order to fulfil this ambition.

\section{THE STRUCTURE OF THE BOOK}

The book is organized into six parts. Part I sets the scene and discusses the fundamentals of small state politics. This first chapter develops a framework for the subsequent analyses and underpins the analytical coherence of the book by identifying a shared starting point for how to understand what we mean by a small state by positing the three fundamental dilemmas of small state politics. This chapter is followed by chapters on small states in world history, the characteristics of politics and policies of small states, the public administration of small states, the political economy of small states and small states in the UN.

The following four parts each explore small state politics within a specific geographical region: Europe, the Middle East and Africa, Central and South America and the Caribbean, and Asia and the Pacific. The final section of the book shifts focus from sovereign small states to semi/non-sovereign small states and territories. For these five sections, analytical coherence is assured, with all authors relating to a shared set of analytical questions: What are the most important domestic characteristics of these states as small states (e.g. social policy, economic policy, political dynamics and public administrative issues)? What are the most important international characteristics of these states as small states (e.g. relations with great/regional powers, participation in regional/international forums)? How do these small states confirm and/or defy our expectations of small states (as vulnerable targets, policy recipients, weak players, etc.)? What are the most important challenges facing these small states, and how do these challenges align with, or relate to, their small size? How do these small states seek to meet, handle and/or overcome these challenges? 


\section{MAIN FINDINGS AND FUTURE RESEARCH TRAJECTORIES}

This volume illustrates the diversity of small states: from poor post-colonial island states of Africa and the Pacific, to the dynamic entrepôt of Singapore in Asia, to resilient and rich democracies in Europe. However, despite their self-evident diversity, taken together the contributions to this volume allow us to identify at least three shared characteristics of small states today.

\section{Capacity and Capabilities Matter}

The politics of small states are restrained by limited capacity and capabilities. The chapters of this volume show that limited capacity and capability have an absolute dimension, a relative dimension and a relational dimension. First, the public administration, politics and political economy of small states all suffer from absolute limitations in capacity and capabilities (Anckar, 2020; Baldacchino, 2020a; Sarapuu and Randma-Liiv, 2020). Limited competition, personal relations and a small marketplace for ideas as well as commodities creates challenges for economic growth, democratic accountability and administrative efficiency. These challenges are often magnified when small states deal bilaterally with stronger powers or seek to influence international society more generally. They have limited diplomatic capacity and their limited economic and military capabilities places them in a weak negotiation position, especially when there is a real threat of economic or military sanctions. Even in relatively safe spaces such as the UN or the EU, small state policies begin from a position of relative weakness that may be either ameliorated or exacerbated by their relations with middle and great powers. Consequently, as shown particularly in the chapters dealing with small states in the UN (Panke and Gurol, 2020), the Nordic countries (Thorhallsson and Elínardóttír, 2020) and Singapore (Chong, 2020), the willingness and ability of small states to think out and implement coping strategies somehow compensates for their material weakness. The contributions to this book show that small states may actively use their status as small (and therefore non-threatening) as a starting point for influence-seeking in ways that are characterized by caution, flexibility, consensus-seeking and coalition-building, preferably within an institutional setting that presumes some basic rules of the game, and sheltering against the most aggressive types of great power behaviour and security.

\section{Institutions Make a Difference}

This points to a second shared characteristic of small states. The right design and management of domestic and international institutions help small states to better face and manoeuvre the challenges ensuing from limited capacity and capabilities. This handbook's analyses of small states in South America (Wehner, 2020), Central America (Long, 2020), Central Asia (Hansen, 2020), East Asia (Buszynski, 2020; Chong, 2020) and Africa (Sanches and Seibert, 2020), as well as the small island and archipelagic 
developing states in the Caribbean (Baldacchino, 2020b) and the Pacific (Corbett and Connell, 2020), illustrate how political leadership becomes decisive in cases of weak political institutions. In contrast, strong domestic institutions in Western Europe have underpinned democratic accountability and administrative effectiveness; they have served as points of departure for Nordic influence and nation branding (Thorhallsson and Elínardóttír, 2020). Rather than the rational design of visionary policy-makers, this is the outcome of century-long political developments including an idiosyncratic mix of war, nationalism, social-democracy and liberal democratic ideology and the willingness and ability to absorb these developments and pragmatically adapt to the role of a small state with limited action space, both domestically and in international affairs. A particular set of institutional characteristics pertain to semi/non-sovereign small states and territories (Berg and Vits, 2020; Criekemans, 2020; Prinsen, 2020). Politics in these small territories is often even more personalized than in sovereign small states. Furthermore, politics is sometimes additionally challenged by geographical dispersion, as many of these entities are islands and archipelagos. Wannabe states are logically challenged by their desire to get something (sovereignty), which they are unlikely to get; but some of them have developed ingenious coping strategies, based on cooperation between regional and national, political and administrative levels. Moreover, where they operate within the purview of a larger, often richer, patron state, non-sovereign small states and entities are often more flexible and less vulnerable than sovereign small states and can afford to worry less about security risks. In their institutional set-up, de facto states tend to mimic sovereign states, but various paradiplomatic initiatives such as representation offices, cultural centres or trade offices and ties between civil societies tend to matter more.

Internationally, institutions provide shelter against external shocks as well as platforms for influence. The UN has underpinned the development and galvanization of the norm of self-determination. It offers influence for small states willing and able to prioritize diplomatic resources, working through regional groups and actively using persuasion strategies to convince third parties (Panke and Gurol, 2020). In Europe, the EU and NATO continue as venues for great power politics as well as shelters and platforms for small states seeking to maximize their interests and influence (Wivel, 2020). In Central Asia, the institutional landscape is relatively densely populated, but institutions such the dying Commonwealth of Independent States (CIS), the EurAsian Economic Union (EAEU), the Collective Security Treaty Organization (CSTO) and the Shanghai Cooperation Organisation (SCO) remain weak and with little independent power or influence (Hansen 2020). In East Asia, ASEAN is at the same time a vehicle for China to assert its claims on the South China Sea onto the participating small states, but at the same time a venue for these small states to occasionally voice their concerns (Buszynski, 2020).

\section{History Creates a Strong Precedence}

Finally, the current political challenges and opportunities of small states are very much the product of history (Masss, 2020). This is most evident in Andorra, 
Liechtenstein, Monaco and San Marino: four European microstates which have political institutions more akin to those common in Europe in the Middle Ages or the Renaissance (Veenendaal, 2020). Also, the relatively late colonization of the Pacific small states results in the persistence of 'pre-modern' and indigenous cultures and traditions, such as the absence of political parties and institutionalized party systems (Corbett and Connell, 2020). The comparative analysis of Malta and Cyprus is illustrative in showing how small island states in the same geopolitical neighbourhood can follow very different historically contingent paths of political and societal development (Pace, 2020). Small states in Africa in particular continue to bear the costs of a past as colonies. Meanwhile, in contrast, some West European small states - Austria, Belgium, Denmark, Greece, Portugal - were themselves, at some point in their history, colonial or imperial centres. In Central and Eastern Europe, a Communist past continues to influence political culture and institutions. In the Balkans, the added experience of the violent break-up of Yugoslavia left the newly created small states in very different positions, in terms of both domestic politics and future access to membership of EU and NATO (Bianchini, 2020). In addition, recent years have seen a 'return of history' with great powers, Russia and China, emphasizing their right to spheres of interest thereby challenging small states in the South China Sea area (Buszynski, 2020), Central Asia (Hansen, 2020) and Eastern Europe and reintroducing the concept of the buffer state (Pedi, 2020).

This handbook's authors also strongly suggest that small states can actively articulate and/or reconstruct their history in useful ways. Singapore and the Nordic countries are examples of states using their past history in present politics to create strong international brands. These brands are typically rooted in political and strategic cultures such as Swedish and Norwegian cultures of peace and engagement, which has allowed them to take on the role of peace mediators, e.g. in the Israeli-Palestinian conflict (Eriksson, 2020).

\section{New Research Agendas}

Our conclusions point to at least two avenues for future research relating the results of this handbook to contemporary scholarly debates. First, a recent wave of scholarship explores the nature and effect of relationality in world politics (e.g. Chamberlain, 2016; Long, 2017; Womack, 2016). This literature shows how “[p]ower asymmetries that favour the stronger state are often combined with asymmetries that favour the weaker one: disparities in intensity of interests, externalities with regard to other relationships, and information about the workings of the other state" (Musgrave, 2019, p. 285). The contributions to this volume show how small states pursue a selection of coping strategies to compensate for material weakness, including allying with other small states or stronger powers, prioritizing resources and organizing smartly. However, the extent to which these strategies allow small states to 'punch above their weight' varies considerably. Previous research has shown that, in times of war, it is the combination of small state and great power strategies in asymmetric conflicts that is decisive for the success of small states (Arreguin-Toft, 2005). The analyses of this 
volume point to the importance of domestic and regional institutions as well as the historical legacy of the state and its relations with other states. They show also that material weakness can be a strategic asset, allowing small states - as well as semiand non-sovereign small territories - a bigger action space and easier access to political, economic and political shelter. Future research would benefit from exploring this relationship between history, institutions and absolute and relative material capacity and capabilities in explaining small state success in asymmetric relationships.

Second, the contributions to this volume add to our knowledge about the relationship between power politics and international institutions. Power politics and international institutions have often been studied separately and analysed as opposites, with institutions viewed as a remedy for or antidote to power politics. However, recent research has explored more complex relationships, seeking to understand how power politics shapes institutional change and innovation at the same time as institutions create and limit the action space for particular types of power politics (Wivel and Paul, 2019). The analyses of this volume suggest how small states are no less focused on maximizing interests and power than great powers have traditionally been. However, their influence is typically negotiated and embedded in international institutions. Future research could profitably explore how these insights add to the growing understanding of how small states seek shelter in multilateral and bilateral relationships (Thorhallsson, 2019) and seek to maximize status in attempts to increase security and influence (de Carvalho and Neumann, 2014).

\section{CONCLUSION}

"Small states are rarely problematic, except to themselves. The drama that unfolds within is rarely enough to generate outsider interest" (Baldacchino, 2018, p. 4). Small states mostly achieve attention from great powers and the international community, when they are perceived as potentially dangerous or in acute need of aid. However, the contributions to this volume show that small states are illustrative of both the dos and the don'ts of politics. Their citizens may not be amused; but smallness and weakness often make such states quaint and interesting laboratories for the representation of political success or fiasco: being represented as resilient or vulnerable to the effects of climate change is an apt contemporary example of this trend (Gay, 2014).

We seek to usurp such nagging parochialism and stereotyping associated with small states as 'banana republics' by offering more scientific and evidence-based discussions of their general characteristics, challenges and opportunities. We activate these general insights in analyses of the politics of small states around the world. The contributions challenge the orthodoxy of those idealizing the small state as well as those viewing small states as inconsequential at best and nuisances to world politics at worst. Small states today may remain restrained by limited capacity and capabilities in pursuing their domestic and international ambitions and are stuck as weak actors in asymmetric relationships, creating dependency and threatening their values 
and interests. However, they also benefit from being weak, since this allows them a bigger action space and success in pursuing coping strategies.

\section{REFERENCES}

Alter, K. J., \& Meunier, S. (2009). The politics of international regime complexity. Perspectives on Politics 7(1), 13-24.

Amstrup, N. (1976). The perennial problem of small states: a survey of research efforts. Cooperation and Conflict 11(2), 163-182.

Anckar, D. (2020). Small states: politics and policies. In G. Baldacchino \& A. Wivel (Eds.), Handbook on the politics of small states (pp. 38-54). Cheltenham, UK and Northampton, MA, USA: Edward Elgar Publishing.

Anderson, B. (2006). Imagined communities: reflections on the origin and spread of nationalism. New York: Verso.

Archer, C., Bailes, A., \& Wivel, A. (Eds.). (2014). Small states and international security: Europe and beyond. London: Routledge.

Archer, C., \& Nugent, N. (2002). Introduction: small states and the European Union. Current Politics and Economics of Europe 11(1), 1-10.

Armstrong, H., Johnes, G., Johnes, J., \& MacBean, A. (1993). The role of transport costs as a determinant of price level differentials between the Isle of Man and the United Kingdom, 1989. World Development 21(2), 311-318.

Armstrong, H. W., \& Read, R. (2002). The phantom of liberty? Economic growth and the vulnerability of small states. Journal of International Development 14(4), 435-458.

Arreguin-Toft, I. (2005). How the weak win wars: a theory of asymmetric conflict. Cambridge: Cambridge University Press.

Bailes, A., Rickli, J. M., \& Thorhallsson, B. (2014). Small states, survival and strategy. In C. Archer, A. Bailes, \& A. Wivel (Eds.), Small states and international security: Europe and beyond (pp. 26-45). London: Routledge.

Baldacchino, G. (2012). Islands and despots. Commonwealth \& Comparative Politics 50(1), 103-120.

Baldacchino, G. (2018). Mainstreaming the study of small states and territories. Small States and Territories 1(1), 3-16.

Baldacchino, G. (2020a). Small states: challenges of political economy. In G. Baldacchino \& A. Wivel (Eds.), Handbook on the politics of small states (pp. 70-82). Cheltenham, UK and Northampton, MA, USA: Edward Elgar Publishing.

Baldacchino, G. (2020b). Island versus region: small states in the Caribbean. In G. Baldacchino \& A. Wivel (Eds.), Handbook on the politics of small states (pp. 278-293). Cheltenham, UK and Northampton, MA, USA: Edward Elgar Publishing.

Baldacchino, G., \& Veenendaal, W. (2018). Society and community. In G. Baldacchino (Ed.), The Routledge international handbook of island studies (pp. 339-352). London: Routledge.

Baldersheim, H., \& Keating, M. (Eds.). (2015). Small states in the modern world: vulnerabilities and opportunities. Cheltenham, UK and Northampton, MA, USA: Edward Elgar Publishing.

Bartmann, B. (2002). Meeting the needs of microstate security. The Round Table: Commonwealth Journal of International Affairs 91(365), 361-374.

Bartmann, B (2007), Island war and security. In G. Baldacchino (Ed.), A world of islands: an island studies reader (pp. 295-324). Charlottetown, Canada and Luqa, Malta: Institute of Island Studies, University of Prince Edward Island and Agenda Academic.

Berg, E., \& Vits, K. (2020). Exploring de facto state agency: negotiation power, international engagement and patronage. In G. Baldacchino \& A. Wivel (Eds.), Handbook on the politics 
of small states (pp. 379-395). Cheltenham, UK and Northampton, MA, USA: Edward Elgar Publishing.

Bianchini, S. (2020). Small states in the Balkans: after Yugoslavia and its 'third way'. In G. Baldacchino \& A. Wivel (Eds.), Handbook on the politics of small states (pp. 189-206). Cheltenham, UK and Northampton, MA, USA: Edward Elgar Publishing.

Briguglio, L. (1995). Small island developing states and their economic vulnerabilities. World Development 23(9), 1615-1632.

Browning, C. (2006). Small, smart and salient? Rethinking identity in the small states literature. Cambridge Review of International Affairs 19(4), 669-684.

Buszynski, L. (2020). Small states, China and the South China Sea. In G. Baldacchino \& A. Wivel (Eds.), Handbook on the politics of small states (pp. 329-342). Cheltenham, UK and Northampton, MA, USA: Edward Elgar Publishing.

Buzan, B. (1993). From international system to international society: structural realism and regime theory meet the English school. International Organization 47(3), 327-352.

Chamberlain, D. P. (2016). Cheap threats: why the United States struggles to coerce weak states. Washington, DC: Georgetown University Press.

Chong, A. (2020). Enlarging Singapore's foreign policy: becoming intermediary for diplomacy, transportation and information. In G. Baldacchino \& A. Wivel (Eds.), Handbook on the politics of small states (pp. 311-328). Cheltenham, UK and Northampton, MA, USA: Edward Elgar Publishing.

Clarke, C. G. (1971). Political fragmentation in the Caribbean: the case of Anguilla. The Canadian Geographer/Le Géographe Canadien 15(1), 13-29.

Cooper, A. F., \& Shaw, T. M. (Eds.). (2009). The diplomacies of small states: between vulnerability and resilience. Basingstoke: Palgrave Macmillan.

Cooper, C., \& Scobell, A. (2014). Carrier dreams or coherent naval strategy? China's aircraft carrier program and what it means for Taiwan. In M. C. M. Chu \& S. L. Kastner (Eds.), Globalization and security relations across the Taiwan Strait: in the shadow of China (pp. 80-92). London: Routledge.

Corbett, J. (2015). Being political: leadership and democracy in the Pacific islands. Honolulu, HI: University of Hawai'i Press.

Corbett, J., \& Connell, J. (2020). Small states in the Pacific. In G. Baldacchino \& A. Wivel (Eds.), Handbook on the politics of small states (pp. 343-361). Cheltenham, UK and Northampton, MA, USA: Edward Elgar Publishing.

Corbett, J., \& Veenendaal, W. (2018). Democracy in small states: persisting against all odds. Oxford: Oxford University Press.

Criekemans, D. (2020). Sub-state diplomacy and wannabe states: proto-diplomacy between dream and nightmare. In G. Baldacchino \& A. Wivel (Eds.), Handbook on the politics of small states (pp. 395-410). Cheltenham, UK and Northampton, MA, USA: Edward Elgar Publishing.

Dahl, R. A., \& Tufte, E. R. (1973). Size and democracy. Stanford, CA: Stanford University Press.

de Carvalho, B., \& Neumann, I. B. (Eds.). (2014). Small state status seeking: Norway's quest for international standing. London: Routledge.

Eriksson, J. (2020). Mediation by small states: Norway and Sweden in the Israeli-Palestinian conflict. In G. Baldacchino \& A. Wivel (Eds.), Handbook on the politics of small states (pp. 207-221). Cheltenham, UK and Northampton, MA, USA: Edward Elgar Publishing.

Fox, A. B. (1959). The power of small states: diplomacy in World War II. Chicago, IL: University of Chicago Press.

Fox, A. B. (1969). The small states in the international system, 1919-1969. International Journal 24(4), 751-764.

Gay, J. C. (2014). Global warming and the exploitation of small island states. L'Espace Géographique 43(1), 81-89. 
Handel, M. (1990). Weak states in the international system. London: Frank Cass.

Hansen, F. S. (2020). Small states in post-Soviet central Asia: navigating between two great power neighbours. In G. Baldacchino \& A. Wivel (Eds.), Handbook on the politics of small states (pp. 294-310). Cheltenham, UK and Northampton, MA, USA: Edward Elgar Publishing.

Hey, J. A. K. (2003). Introducing small state foreign policy. In J. A. K. Hey (Ed.), Small states in world politics: explaining foreign policy behaviour (pp. 1-11). Boulder, CO: Lynne Rienner.

Iceland UN Mission (2008). Model UN. Retrieved from https://www.iceland.is/iceland -abroad/un/nyc/islenska/raedur-og-frettir/model-un/6617/.

Janis, I. L. (1982). Groupthink: psychological studies of policy decisions and fiascoes. Boston, MA: Houghton Mifflin.

Kassim, Y. R. (2012). S5 vs. P5: the rise of the small states? RSIS Commentaries 187/2012. Singapore: S. Rajaratnam School of International Studies, Nanyang Technological University. Retrieved from https://www.rsis.edu.sg/wp-content/uploads/2014/07/CO12187.pdf.

Knudsen, O. F. (2002). Small states, latent and extant: towards a general perspective. Journal of International Relations and Development 5(2), 182-198.

Krause, V. J., \& Singer, J. D. (2001). Minor powers, alliances and armed conflict: some preliminary patterns. In E. Reiter \& H. Gärtner (Eds.), Small states and alliances (pp. 15-23). Vienna: Physica-Verlag.

Lake, D. A. (2013). Theory is dead, long live theory: the end of the great debates and the rise of eclecticism in international relations. European Journal of International Relations 19(3), $567-587$.

Long, T. (2017). It's not the size, it's the relationship: from 'small states' to asymmetry. International Politics 54(2), 144-160.

Long, T. (2020). Small states in Central America. In G. Baldacchino \& A. Wivel (Eds.), Handbook on the politics of small states (pp. 242-258). Cheltenham, UK and Northampton, MA, USA: Edward Elgar Publishing.

Løvold, A. (2004). Småstatsproblematikken i internasjonal politikk. Internasjonal Politikk 62(1), 7-31.

Maass, M. (2009). The elusive definition of the small state. International Politics 46(1), 65-83.

Maass, M. (2017). Small states in world politics: the history of small state survival 1648-2016. Manchester: Manchester University Press.

Maass, M. (2020). Small states: surviving, perishing and proliferating through history. In G. Baldacchino \& A. Wivel (Eds.), Handbook on the politics of small states (pp. 20-37). Cheltenham, UK and Northampton, MA, USA: Edward Elgar Publishing.

Marriott, R. (1943). Federalism and the problem of the small state. London: Allen \& Unwin.

McIntyre, W. D. (2012). The partition of the Gilbert and Ellice Islands. Island Studies Journal 7(1), 135-146.

Mearsheimer, J. J. (2014). The tragedy of great power politics, New York: W. W. Norton.

Menon, J. (2014). From spaghetti bowl to jigsaw puzzle? Fixing the mess in regional and global trade. Asia \& the Pacific Policy Studies 1(3), 470-483.

Molis, A. (2006). The role and interests of small states in developing European security and defence policy. Baltic Security and Defense Review 8(1), 81-100.

Mouritzen, H., \& Wivel, A. (2005). Introduction. In H. Mouritzen \& A. Wivel (Eds.), The geopolitics of Euro-Atlantic integration (pp. 1-11). London: Routledge.

Murray, D. J. (1981). Microstates: public administration for the small and beautiful. Public Administration and Development 1(3), 245-256.

Musgrave, P. (2019). Asymmetry, hierarchy and the Ecclesiastes trap. International Studies Review 21(2): 284-300. 
Neumann, I. B., \& Gstöhl, S. (2006). Introduction: Lilliputians in Gulliver's world? In C. Ingebritsen, I. B. Neumann, S. Gstöhl, \& J. Beyer (Eds.), Small states in international relations (pp. 3-36). Seattle, WA: University of Washington Press.

Ott, D. (2000). Small is democratic: an examination of state size and democratic development. London: Psychology Press.

Pace, R. (2020). The non-identical Mediterranean island states: Cyprus and Malta. In G. Baldacchino \& A. Wivel (Eds.), Handbook on the politics of small states (pp. 131-149). Cheltenham, UK and Northampton, MA, USA: Edward Elgar Publishing.

Paci, D. (2015) Corsica fatal, Malta baluardo di romanità: L'irredentismo fascista nel mare nostrum 1922-1942. Florence and Milan: Le Monnier-Mondadori Education.

Panke, D., \& Gurol, J. (2020). Small states: challenges and coping strategies in the UN General Assembly. In G. Baldacchino \& A. Wivel (Eds.), Handbook on the politics of small states (pp. 83-98). Cheltenham, UK and Northampton, MA, USA: Edward Elgar Publishing.

Pedi, R. (2020). Small states in Europe as a buffer between East and West. In G. Baldacchino \& A. Wivel (Eds.), Handbook on the politics of small states (pp. 168-188). Cheltenham, UK and Northampton, MA, USA: Edward Elgar Publishing.

Prinsen, G. (2020). Small, subnational jurisdictions. In G. Baldacchino \& A. Wivel (Eds.), Handbook on the politics of small states (pp. 362-378). Cheltenham, UK and Northampton, MA, USA: Edward Elgar Publishing.

Raadschelders, J. B. (1992). Definitions of smallness: a comparative study. In R. A. Baker (Ed.), Public administration in small and island states (pp. 26-33). West Hertford, CT: Kumarian Press.

Richards, J. (1982). Politics in small independent communities: conflict or consensus? Journal of Commonwealth \& Comparative Politics 20(2), 155-171.

Rickli, J. M., \& Almezaini, K. S. (2017). Theories of small states' foreign and security policies. In K. S. Almezaini \& J. M. Rickli (Eds.), The small Gulf states: foreign and security policies before and after the Arab Spring (pp. 8-30). London: Routledge.

Rodrigues Sanches \& Seibert, G. (2020). Politics and economy in small African island states: comparing Cabo Verde and São Tomé y Príncipe. In G. Baldacchino \& A. Wivel (Eds.), Handbook on the politics of small states (pp. 222-241). Cheltenham, UK and Northampton, MA, USA: Edward Elgar Publishing.

Sarapuu, K., \& Randma-Liiv, T. (2020). Small states: public management and policy-making. In G. Baldacchino \& A. Wivel (Eds.), Handbook on the politics of small states (pp. 55-69). Cheltenham, UK and Northampton, MA, USA: Edward Elgar Publishing.

Sil, R., \& Katzenstein, P. J. (2011). De-centering, not discarding, the 'isms': some friendly amendments. International Studies Quarterly 55(2), 481-485.

Srebrnik, H. (2004). Small island nations and democratic values. World Development 32(2), $329-341$.

Thorhallsson, B. (2006). The size of states in the European Union: theoretical and conceptual perspectives. European Integration 28(1), 7-31.

Thorhallsson, B. (Ed.). (2019). Small states and shelter theory: Iceland's external affairs. London: Routledge.

Thorhallsson, B., \& Elínardóttír, J. S. (2020). Nordic states: keeping cool at the top? In G. Baldacchino \& A. Wivel (Eds.), Handbook on the politics of small states (pp. 113-130). Cheltenham, UK and Northampton, MA, USA: Edward Elgar Publishing.

Thorhallsson, B., \& Steinsson, S. (2017). Small state foreign policy. Oxford research encyclopaedia of politics. Oxford: Oxford University Press.

Thorhallsson, B., \& Wivel, A. (2006). Small states in the European Union: what do we know and what would we like to know? Cambridge Review of International Affairs 19(4), 651-668.

Värynen, R. (1971). On the definition and measurement of small power status. Cooperation and Conflict 6(1), 91-102. 
Veenendaal, W. P. (2020). Politics of the four European microstates: Andorra, Liechtenstein, Monaco and San Marino. In G. Baldacchino \& A. Wivel (Eds.), Handbook on the politics of small states (pp. 150-167). Cheltenham, UK and Northampton, MA, USA: Edward Elgar Publishing.

Vital, D. (1967). The inequality of states: a study of the small power in international relations. Oxford: Clarendon Press.

Wehner, L. E. (2020). The foreign policy of South American small powers in regional and international politics. In G. Baldacchino \& A. Wivel (Eds.), Handbook on the politics of small states (pp. 259-277). Cheltenham, UK and Northampton, MA, USA: Edward Elgar Publishing.

Wendt, A. (1992). Anarchy is what states make of it: the social construction of power politics. International Organization 46(2), 391-425.

Wimmer, A. (2012). Waves of war: nationalism, state formation and ethnic exclusion in the modern world. Cambridge: Cambridge University Press.

Wivel, A. (2016). Living on the edge: Georgian foreign policy between the West and the rest. Third World Thematics: A TWQ Journal 1(1), 92-109.

Wivel, A. (2020). Small states in Europe. In G. Baldacchino \& A. Wivel (Eds.), Handbook on the politics of small states (pp. 99-112). Cheltenham, UK and Northampton, MA, USA: Edward Elgar Publishing.

Wivel, A., Bailes A., \& Archer C. (2014). Setting the scene: small states and international security. In C. Archer, A. Bailes, \& A. Wivel (Eds.), Small states and international security: Europe and beyond (pp. 3-25). London: Routledge.

Wivel, A., \& Paul, T. V. (2019). International institutions and power politics: bridging the divide. Washington, DC: Georgetown University Press.

Womack, B. (2016). Asymmetry and international relationships. Cambridge: Cambridge University Press.

World Bank (2017). Small states: a roadmap for World Bank group engagement. Washington, DC: Operations Policy and Country Services. 